Dagmara Nowakowska

Wydział Filologii Polskiej i Klasycznej,

Uniwersytet im. Adama Mickiewicza w Poznaniu

Alicja Przybyszewska

Ośrodek Dokumentacji Wielkopolskiego Środowiska Literackiego,

Biblioteka Raczyńskich w Poznaniu

\title{
Pisarz w archiwum. Prace nad poznańskim Archiwum Włodzimierza Odojewskiego
}

W kwietniu bieżącego roku odbył się cykl wydarzeń poświęconych Włodzimierzowi Odojewskiemu, pisarzowi, publicyście, krytykowi literackiemu i autorowi słuchowisk radiowych. Na Wydziale Filologii Polskiej i Klasycznej UAM miało miejsce drugie spotkanie badaczy, czytelników i miłośników dzieła autora Kwarantanny na ogólnopolskiej konferencji naukowej Zapomniane, nieuśmierzone. Pamięć, zapomnienie, trauma w twórczości Włodzimierza Odojewskiego. Konferencji towarzyszyła wystawa biograficzno-literacka Jedźmy, wracajmy... Drogi życia i szlaki twórcze Włodzimierza Odojewskiego, której ważny akcent stanowiła prezentacja opowiadania Ku Dunzynańskiemu Wzgórzu idzie las w wykonaniu Janusza Andrzejewskiego i Piotra Orlińskiego. Celem tych wydarzeń było przypomnienie dorobku jednego z najwybitniejszych przedstawicieli polskiej prozy powojennej i przywrócenie go do refleksji badawczej. Zainspirowane zostały materią archiwum pisarskiego, które - latami przez autora gromadzone - znajduje się w specjalnie przygotowanej pracowni na poznańskiej polonistyce. Podobnie jak poprzednim razem organizatorom tegorocznej konferencji i wystawy przyświecały tytuły książek Odojewskiego, odzwier- 
ciedlające w pewnym sensie koleje życia i twórczości ich autora, dynamikę i podstawowe założenia jego pisarstwa ${ }^{1}$.

Niniejszy tekst powstał wskutek refleksji, które pojawiały się w trakcie opracowywania prywatnego archiwum Odojewskiego oraz wystawy biograficzno-literackiej. Nie wyczerpuje tematu, a raczej ma za zadanie wytyczyć potencjalne ścieżki badań nad życiem i twórczością pisarza, które doprowadzą do powstania jego biografii. Mamy tu do czynienia ze swego rodzaju hermeneutyką archiwaliów, próbą odszyfrowania tropów i zinterpretowania detali, by ułożyły się w opowieść. Materiał archiwalny nadaje rytm pracy i weryfikuje metody działania osoby, która podjęła się sklasyfikowania go i odczytania.

\section{Biografia i archiwum}

Urodzony w 1930 roku w Poznaniu Odojewski związał los swej twórczej spuścizny z rodzinnym miastem. W stolicy Wielkopolski spędził okres dzieciństwa i wczesnej młodości. Na czas okupacji przeniósł się z matką Genowefą z Zawodnych Jasińską do Kłecka pod Gnieznem, gdzie po raz pierwszy zetknął się z realiami wojennej rzeczywistości. Niebawem zaobserwował też grozę pogranicza polsko-ukraińskiego, gdy - jako trzynastolatek - spędził swe ostatnie wakacje na Podolu. Ruina kresowej Rzeczpospolitej, tak dobrze znanej z letnich, przedwojennych podróży, mocno wpłynęła na wyobraźnię młodego Odojewskiego. Wsparta wieloletnimi studiami historii Kresów Wschodnich dała materię fabularną szeregowi powieści i opowiadań. Zanim jednak to nastąpiło, w 1948 roku Odojewski zdał maturę w Szczecinie, podjął pierwsze próby pisarskie i powrócił do Poznania, gdzie rozpoczął pracę dzienni-

1 Pierwszym wydarzeniem, które poświęcone zostało autorowi Oksany, było zorganizowane w marcu 2017 roku na Wydziale Filologii Polskiej i Klasycznej UAM spotkanie naukowe Zabezpieczanie śladów. Sympozjum pamięci Wtodzimierza Odojewskiego. Spotkaniu towarzyszył panel dyskusyjny w Bibliotece Raczyńskich z udziałem rodziny pisarza, badaczy, czytelników i innych osób bliskich, których miejsce w biografii Odojewskiego okazało się istotne. Pokłosiem spotkania jest książka Zabezpieczanie śladów: wokót życia i twórczości Wtodzimierza Odojewskiego, red. D. Nowakowska, A. Przybyszewska, Poznań 2018. 
karską i studia uniwersyteckie. Niebawem zadebiutował tomem opowiadań Opowieści leskie i został członkiem Związku Literatów Polskich. Na łamach „Tygodnika Zachodniego” zamieszczał felietony, szkice i pamflety składające się na cykl „Bez dogmatów”. Utrzymane w tonie rozrachunkowym stały się niebawem przyczyną objęcia dzieł pisarza zakazem druku, czego efektem było zatrzymanie przez cenzurę edycji dwóch książek Odojewskiego.

W roku 1959 pisarz przeniósł się do Warszawy. Niebawem, dzięki interwencji Jerzego Putramenta, otrzymał pracę w redakcji Studia Współczesnego Teatru Polskiego Radia, a jego książki powróciły na rynek czytelniczy. Opublikowany w 1962 roku zbiór opowiadań Zmierzch świata, a dwa lata później powieść Wyspa ocalenia zapoczątkowały najważniejsze dzieło Odojewskiego - cykl podolski. W 1971 roku wyjechał na stypendia twórcze do Paryża i Berlina. Rok później osiedlił się w Monachium, gdzie podjął pracę w rozgłośni polskiej Radia Wolna Europa. Niedługo potem w Instytucie Literackim w Paryżu ukazała się powieść Zasypie wszystko, zawieje..., wieńcząca trylogię cyklu podolskiego. Lata spędzone w monachijskiej rozgłośni były dla Odojewskiego okresem intensywnej pracy publicystycznej, a ukazujące się wówczas tomy opowiadań stanowią zapis emigracyjnego doświadczenia autora. Odojewski mieszkał w Monachium do 2014 roku, a ostatnie lata życia spędził w Warszawie. Przed śmiercią przekazał całą swą literacką spuściznę Wydziałowi Filologii Polskiej i Klasycznej UAM, gdzie obecnie mieści się Archiwum Włodzimierza Odojewskiego.

Życiowe wybory pisarza wplynęły znacząco na realizowaną przez niego metodę gromadzenia i archiwizacji dokumentów życia i twórczości. Podejmowane co jakiś czas, zwykle w trudnych życiowych okolicznościach, przeprowadzki nie sprzyjały stabilności pisarskiego archiwum. Dziesięcioletni pobyt w Poznaniu, zakończony utratą pracy w redakcji „Tygodnika Zachodniego”, jest słabo udokumentowany w pozostawionej przez pisarza spuściźnie. Następujący po nim, trwający kolejną dekadę, warszawski okres biograficzny, naznaczony był sporą intensywnością publikowania i wzrastającą pozycją Odojewskiego w życiu literackim. Przerwany został decyzją o przeprowadzce na Zachód i nieprecyzyjnie 
nazywany jest niekiedy emigracją pisarza z Polski. W Monachium Odojewski spędził najdłuższy, bo trwający czterdzieści trzy lata, etap swej biografii, dlatego tu zgromadzony został największy korpus materiałów, czyli domowe archiwum pisarza. $Z$ tego względu dominują w nim dokumenty i teksty utworzone w drugiej połowie życia autora Oksany, a najważniejszym akcentem jego twórczej aktywności tego okresu stała się praca nad cyklem podolskim. Archiwum domowe Odojewskiego znajduje uzupełnienie i dopełnienie $\mathrm{w}$ dokumentacji przechowywanej w innych instytucjach, których mapę wyznaczają drogi życia pisarza: Archiwum Uniwersytetu Adama Mickiewicza, Archiwum Wydawnictwa Poznańskiego w Bibliotece Raczyńskich w Poznaniu, Archiwum Polskiego Radia, wreszcie Biblioteka Instytutu Polskiego w Paryżu oraz Archiwum Emigracji Polskiej w Toruniu.

Spuścizna pozostawiona przez Odojewskiego dokumentuje różne obszary biografii i twórczej aktywności pisarza, a także recepcję jego dzieła, stanowiąc wyzwanie naukowe o charakterze interdyscyplinarnym². Prace inwentaryzacyjne, respektując odautorski porządek materiałów, zmierzają ku stworzeniu układu zbiorów, który będzie eksponował wartość poznawczą i potencjał badawczy archiwaliów. Materia pozyskanej dokumentacji pozwala usytuować ją w kręgu zainteresowań historyków, regionalistów, biografów, historyków literatury, a nade wszystko - tekstologów, zorientowanych na rekonstrukcję genezy dzieła literackiego. Pozostając w orbicie podstawowych i pożytecznych przy inwentaryzacji zbiorów podziałów, poniżej wskazano niektóre obszary naukowej eksploracji. Podkreślono jednocześnie drogi i metody uzupełniania archiwum i wprowadzania tworzących go materiałów do badawczego obiegu³.

Zawartość przekazanego przez autora Zmierzchu świata zasobu została zaprezentowaną przez Dagmarę Nowakowską w tekście Poznańskie Archiwum/Pracownia Wtodzimierza Odojewskiego [Nowakowska 2016; zob. też Nowakowska, Nawrot, Krystek 2017].

3 Owo wprowadzanie do badawczego obiegu zostało określone przez badaczy archiwum Zbigniewa Herberta poprzez metaforę animizacji, „ożywiania archiwum”, uczynienia go na powrót pracownią [zob. Antoniuk, red. 2017: 37-41]. 


\section{Mapowanie biografii}

Mechanizm powstawania spuścizny literackiej pozostaje indywidualną sprawą twórczego zamysłu autora. Niekiedy konieczność gromadzenia dokumentów życia i twórczości wiąże się z określonym etapem pisarskiej biografii; często jednak badacz staje wobec zasobu narastającego przez wiele lat, z różną intensywnością i pieczołowitością przez autora przygotowywanego. Badawcza eksploracja autorskiego archiwum wiąże się z odkrywaniem określonej strategii autokreacyjnej, która bywa niestabilna i zmienna. Zważywszy, że każdy pozostawiony w archiwum dokument, od autografu wiersza po bilet tramwajowy, w porządku spuścizny autora otrzymuje status faktu biograficznego, najważniejszym dla opracowania zasobu na użytek badawczy zabiegiem staje się rozpoznanie sposobu organizowania materii biograficznej przez autora.

Podążając za podziałem Edwarda Balcerzana [1975: 32], można wyróżnić dwie strategie autorskie w tym zakresie: pierwsza to świadomie konstruowana biografia wycofana, wtopiona w samą twórczość; druga to puszczanie w obieg ruchomego archiwum: rękopisów, dedykacji, listów, rysunków, z intencją powiedzenia tego, czego odbiorcy nie znajdą w książkach. Spojrzenie pod tym kątem na zasób pozostawiony przez Odojewskiego pozwala usytuować jego zbiory na pograniczu obu strategii, czego dowodem są z jednej strony obecne w twórczości tropy biograficzne (dokładne datowanie wariantów opowiadań i powieści, autorskie przedmowy, biografia pisarza i osób jemu bliskich jako materia fabularna), a z drugiej strony obszerna, wielogatunkowa i niekiedy wielogłosowa dokumentacja warsztatowa, ujawniająca etapy powstawania tekstów. Wiedza o autorskim zwyczaju i kierunkach gromadzenia zasobu pozwala także uzupełniać pozostawione przez pisarza zbiory, pozyskiwać wiedzę o materiałach rozproszonych w innych instytucjach i u osób prywatnych.

Pomimo tych zabiegów autorskie archiwum nigdy nie zyskuje jednak statusu zasobu kompletnego. Pozostaje bytem otwartym, nie tylko na materialne dopełnienie w postaci nowych zbiorów, ale także na wielość odczytań, które potencjalnie w sobie mieści. Ta sytuacja, powszechna dla pisarskich spuścizn, dyktuje model 
pisania biografii Odojewskiego, który winien opierać się na platformie cyfrowej, transponującej metodologię pracy faktograficznej w formę otwartego kalendarium życia i twórczości autora Kwarantanny. Dla takiego cyfrowego kalendarium najwłaściwsza wydaje się struktura mapy, której podstawowe punkty wyznaczone zostaną przez miasta i domy, zgodnie z kolejami życia autora: Poznań - Kłecko - Podole - Gniezno - Szczecin - Poznań - Warszawa - Berlin - Paryż - Monachium - Warszawa [zob. Nowakowska 2014: 5-13; Przybyszewska 2018]. Metodę „mapowania” biografii podpowiada także poniekąd dorobek Odojewskiego, wpisującego topografię w tytulaturę lub fabułę utworów (cykl podolski, Powieść berlińska, Spotkanie w Dubrowniku, Lekcja intymności, Ostatni Żyd w miasteczku i in.). Monachijskie archiwum Odojewskiego okazało się nadto rekwizytornią pamiątek rodzinnych i osobistych, pozwalających skrzyżować mapę miejsc z mapą domów, a sylwetkę twórcy/artysty uzupełnić o obraz syna, brata, męża i ojca. Sztambuch matki Genowefy, albumy fotografii Jasińskich i Bystrzyckich, oprawione w ramy zdjęcia bliskich osób, ich wspomnienia i relacje sprzyjają natomiast odtworzeniu kultury artystycznoliterackiej domu rodzinnego i zestawu lektur młodego Odojewskiego. Rodzinne opowieści trafiły także po latach do jego prozy.

\section{Mapowanie biografii, etap pierwszy: Kłecko. Dajewscy}

$\mathrm{Z}$ pobytem w Kłecku i rodziną ze strony matki pisarza wiąże się zainteresowanie Katyniem, o czym Odojewski lapidarnie wspomniał w kilku wywiadach. Ciotka pisarza, Janina Dajewska, straciła tam swojego męża. Po odkryciu polskich grobów pojechała do Katynia z nadzieją na przywiezienie ciała małżonka do Polski, by spoczął w rodzinnym grobowcu. Tym krewnym Odojewskiego był Marceli Dajewski, urodzony 5 kwietnia 1906 roku w Lesznie, sędzia Sądu Grodzkiego w Pleszewie, podporucznik rezerwy, aresztowany przez NKWD we wrześniu 1939 roku. Był więźniem obozu w Kozielsku. Dajewska oczekiwała wówczas narodzin ich pierwszego dziecka, córki Barbary, która nigdy nie poznała swojego ojca. Dajewski został zamordowany w kwietniu 1940 roku w Katyniu, 
miał wówczas 34 lata. Jego historia była dobrze znana w rodzinie pisarza dzięki jednej z sióstr matki, Julii Zawodnej z Kłecka. Julia, nazywana w rodzinie ciotką Julą, utrzymywała bliskie kontakty z Janiną Dajewską i na bieżąco informowała rodzinę o sprawie katyńskiej. Po wojnie Dajewska wraz z córką zamieszkały w miejscowości Odrzykoń na Podkarpaciu. Temat katyński pojawi się jeszcze podczas rodzinnych rozmów w domu Odojewskiego przy innej okazji.

\section{Mapowanie biografii, etap drugi: Poznań. Bystrzyccy}

Odojewski, zdobywając coraz większe doświadczenie w pracy dziennikarskiej i pisarskiej, w połowie lat 50. xx wieku przez małżeństwo z Janiną z Bystrzyckich wszedł do zamożnej rodziny $\mathrm{z}$ tradycjami literackimi, rodziny - dodajmy - o arystokratycznych korzeniach, mającej z tego powodu spore kłopoty w okresie powojennym 4 . Bolesław Bystrzycki, ojciec Janiny, przemysłowiec z wielkopolskiego Orzechowa, urodzony w Przemyślu, był synem Michała, wiceprezydenta miasta Przemyśla, i Zofii z Bitnerów. Miał trzech braci: Tadeusza (inżyniera, który - jak ojciec - został włodarzem rodzinnego miasta), Kazimierza i Jana. Ożenił się z Janiną Sczaniecką. Kuzynem żony Odojewskiego był o siedem lat starszy od niego Przemysław Bystrzycki, syn Tadeusza, pisarz, dziennikarz i żołnierz cichociemny, w latach 5o. ubiegłego wieku należący do kolegium redakcji szczecińskiego pisma kulturalno-społecznego „Ziemia i Morze” i poznańskiego „Tygodnika Zachodniego”, z którymi związany był także Odojewski. W latach 1959-1962 Bystrzycki współpracował z tygodnikiem londyńskim „Oblicze Tygodnia”, natomiast począwszy od 1965 roku przez trzy lata pełnił funkcję kierownika literackiego miesięcznika „Nurt”. Był także wiceprezesem Poznańskiego Oddziału Związku Literatów Polskich, należał do polskiego PEN Clubu oraz Towarzystwa Literackiego im. Adama Mickiewicza natomiast siostra Bystrzyckiego, Zofia, była powieściopisarką i żoną Jerzego Putramenta. 
Odojewski zamieszkał z Janiną w rodzinnym domu Bystrzyckich, w willi na poznańskim Sołaczu. Do tego właśnie domu przy alei Wielkopolskiej wprowadził się w latach 50. przyjaciel Odojewskiego Kazimierz Orlewicz. Miało to związek z ówczesnymi normatywami mieszkaniowymi, według których jednej osobie przysługiwała ściśle określona powierzchnia użytkowa mieszkania, a liczba pokoi zależała od liczby osób wchodzących w skład gospodarstwa domowego. Aby uniknąć dokwaterowania sublokatora, Odojewski sprowadził Orlewicza, który był wówczas dziennikarzem „Expressu Poznańskiego”.

Na kartach powstałego w 1963 roku opowiadania Spisywane $z$ pamięci z tomu Jedźmy, wracajmy pojawiają się nawiązania do pamiętnych wydarzeń Poznańskiego Czerwca. Bohater opowiadania, obserwator, bierny uczestnik czerwcowych wypadków, zamknięty w celi aresztu, przywołuje niemal fotograficzny obraz swej przestrzeni życiowej:

[...] dom przy Alei, przed domem ogród, drzewa stojące bez ruchu w dusznym upale tego czwartku, bezchmurne niebo, pusta ulica i niedaleko karabinowa palba [...]. W gęstym dwuszeregu rozłożystych kasztanów - aleja, w ich cieniu zielono pomalowane ławki ustawione symetrycznie [...] w ogrodach dwa rzędy domków jednorodzinnych willi, żółtych, białych albo żółto-białych [...] dalej na kamienistym nasypie z rzadka porosłym trawą, tu i ówdzie wypaloną i sczerniałą, kolejowy tor [...] parę czworoboków wyższych budynków, przeważnie secesyjnych kamienic czynszowych, między którymi wznosił się szpital imienia Raszei, opodal zabudowania otaczające gmach Urzędu Bezpieczeństwa, górujący nad resztą otoczenia. [Odojewski 2000: 328-330]

Odojewski był w czasie wydarzeń czerwcowych w Poznaniu, a fragment o domu przy kasztanowej alei prowadzącej do nasypu i torów kolejowych i dalej do centrum, zwłaszcza osobom znającym topografię Poznania, przywodzi na myśl okolicę, w której wówczas mieszkał z żoną, oraz dom Bystrzyckich przy alei Wielkopolskiej. Podobnie jak bohater opowiadania Odojewski oczekiwał 
wówczas narodzin dziecka. Córka pisarza Katarzyna przyszła na świat 7 grudnia 1956 roku.

Tropy prowadzące do historii Bystrzyckich i ich zesłańczych doświadczeń pojawiają się $\mathrm{w}$ opowiadaniach łagrowych $\mathrm{z}$ tomu Zabezpieczanie śladów oraz w utworze Udany weekend, zawartym w książce Bez tchu. W dramatycznych losach rodziny obecny jest także wątek katyński [Dabertowa 2005; Sztaba, Sarkady, red. 2010]. Tadeusz Bystrzycki, stryj żony Odojewskiego, w kwietniu 1940 roku został aresztowany przez Sowietów i uwięziony w Przemyślu, później we Lwowie, a następnie zamordowany w więzieniu NKWD w Kijowie przy ul. Karolenkiwskiej 17. Jego nazwisko znalazło się na tzw. Ukraińskiej Liście Katyńskiej, opublikowanej w 1994 roku. Tadeusz Bystrzycki pochowany został na Polskim Cmentarzu Wojennym w Kijowie-Bykowni. Trzy dni po aresztowaniu Tadeusza podobny los spotkał jego rodzinę: żonę Helenę, teściową Zuzannę Stankiewiczową, syna Przemysława oraz trzy córki: Zofię, Wieńczysławę i Dobromiłę. Wszyscy wywiezieni zostali w głąb ZSRR do Kazachstanu, podobnie jak bohater wspomnianych opowiadań Odojewskiego. Przemysław Bystrzycki w maju 1941 roku podjął ucieczkę z kołchozu, pokonał pieszo trzy tysiące kilometrów stepu i dotarł do Charkowa, gdzie został aresztowany i skazany na dziesięć lat łagrów. W tym samym roku we wrześniu zwolniono go z więzienia w na mocy układu Sikorski-Majski. Wtedy zgłosił się do formowanej przez generała Władysława Andersa Armii Polskiej na Wschodzie. Jako cichociemny w 1944 roku znalazł się na terenie okupowanej Polski, na Podhalu. W następnym roku aresztowany przez UB, został zwolniony z krakowskiego więzienia na mocy amnestii. Wtedy przeniósł się do Poznania, gdzie ukończył ekonomię i socjologię na Uniwersytecie Poznańskims. na ten temat (pisarz czytał m.in. Inny świat Gustawa Herlinga-Grudzińskiego, Wielką czystkę Aleksandra Weissberga-Cybulskiego i Ciemność w potudnie Arthura Koestlera), ale ok. roku 1963, kiedy powstawały jego opowiadania List, Spisywane z pamięci oraz „I Duch się skupit w jedno ziarno”, jeszcze nie było polskiej literatury łagrowej (Cedrowe orzechy. Opowiadania syberyjskie Zbigniewa Domino po raz pierwszy wydano w 1974 roku, natomiast powieść Wielbtąd na stepie Jerzego Krzysztonia została opublikowana w roku 1978). Można więc założyć, że bliskie 
Na podobieństwo fabuł opowiadań Odojewskiego List, Spisywane z pamięci czy „I Duch się skupit w jedno ziarno” zwróciła uwagę Magdalena Rabizo-Birek. Zasugerowała, że mogła być to jedna lub dwie relacje poddane różnym literackim obróbkom, na co wskazuje powtarzalność pewnych wątków - np. narratora, którym jest młody chłopiec zesłany do Kazachstanu i podejmujący ucieczkę, by wydostać się z Rosji - a także motywu pracy pasterza czy pracy w kopalni, okrucieństwa strażników, niebezpiecznej wędrówki przez nieprzyjazne człowiekowi tereny [Rabizo-Birek 2002: 115] ${ }^{6}$; w opowiadaniach Udany weekend i Ku Dunzynańskiemu Wzgórzu idzie las wykreowana postać dziennikarza emigranta, zawikłanego w sprawę czy rozpamiętującego zesłańcze losy swoich bliskich, to porte parole Odojewskiego.

\section{Korespondencja. Epicentrum emigracji polskiej}

Obecny stan wiedzy o korespondencji Odojewskiego jest znikomy. Pisarz publikował pojedyncze listy w prasie, m.in. w „Rzeczpospolitej” i „Tygodniku Powszechnym”, a te wybrane do druku według tylko jemu znanego klucza zostały opatrzone glossą objaśniającą okoliczności ich napisania i relacje łączące nadawcę z adresatem. To zaledwie namiastka prywatnej kolekcji Odojewskiego. Gromadzona przez całe życie pisarza korespondencja stanowi kontekst historycznokulturowy zarówno dla badań biografistycznych, jak i interpretacji twórczości pisarza, a także jest bezcennym źródłem dla powojennej historii Polski. To ważny dokument epoki i świadectwo działalności i życia polskiej powojennej emigracji intelektualnej oraz kronika wydarzeń kulturalnych. Zasób ujawnia różne punkty widzenia, przyjaźnie i sympatie, konflikty interesów, animozje i spory, a nawet plotki, którymi żyła emigracja; przynosi także zabawne anegdoty. Zagłębiając się w korespondencję Odojewskiego z Witoldem Wirpszą, dowiadujemy się np., jak funkcjo-

kontakty z Bystrzyckimi, zwłaszcza z Przemysławem, rozpalały twórczą wyobraźnię pisarza.

6 Inga Iwasiów [1994: 49] doszukuje się podobieństwa opowiadania List do powieści Zasypie wszystko, zawieje, wskazując wątek wuja Augusta. 
nowała „konspiracja” w RWE. Pseudonimy twórców pozostających w kraju, których teksty nadawała rozgłośnia, miały uchronić ich przed represjami ze strony władz PRL. Aleksander Wirpsza, syn Witolda, publikował nie tylko pod pseudonimem Leszek Szaruga, ale również jako Krzysztof Powoski. Twórczość Powoskiego była komentowana przez Witolda Wirpszę. W jednej ze swych wypowiedzi autor Przesądów zaatakował Powoskiego za bałamuctwa, które zamieścił w recenzji książki Wiktora Woroszylskiego. Jak się okazuje, Wirpsza [1980] był zupełnie nieświadomy tego, że recenzuje teksty własnego syna.

Na szczególną uwagę zasługuje zachowana w archiwum korespondencja Odojewskiego z Jerzym Giedroyciem. Jest to dziewięćdziesiąt dziewięć listów napisanych do autora Ikonki Siergieja w latach 1972-2000. Już w pierwszych listach Giedroycia pisarz traktowany jest jak ambasador polskiej kultury i krajowych środowisk literackich na Zachodzie. Twórca Instytutu Literackiego utwierdzał go w przekonaniu, że kontakty z autorami krajowymi są sprawą kluczową przede wszystkim w kwestii pozyskiwania materiałów. Nie ma wątpliwości, że od początku współpracy Odojewskiego z RWE wpływ Giedroycia na jego twórczość był znamienny. Można nawet pokusić się o stwierdzenie, że w pewnym sensie kształtował on Odojewskiego jako krytyka literackiego i publicystę, a także emigracyjnego promotora polskiej literatury. Giedroyć występuje w listach jako doradca młodszego kolegi po piórze, ułatwiający Odojewskiemu kontakty z wpływowymi osobistościami ze świata polityki i kultury, m.in. z profesorem Zbigniewem Brzezińskim, i udzielający mu swojego wsparcia w niewygodnych sytuacjach, takich jak spór z Janem Nowakiem-Jeziorańskim w 1973 roku. Angażował Odojewskiego w organizację rozmaitych akcji w niemieckich kołach uniwersyteckich i literackich, które wspierały finansowo emigrantów przybywających z PRL. Przy okazji omawiania tych projektów pojawiają się we wspomnianej korespondencji nazwiska polskich twórców osiadłych w Berlinie: Zbigniewa Herberta, Adama Zagajewskiego, Witolda Wirpszy czy Ryszarda Krynickiego.

W listach omawiane są wydarzenia kulturalne odbywające się w kraju, np. okoliczności wystawienia Ślubu Witolda Gombrowi- 
cza w Teatrze Dramatycznym w Warszawie i sprawa publikacji jego Dzienników, co według ostatniej woli ich autora miało zaważyć na drukowaniu jego twórczości w Polsce; innym przykładem jest wydanie Loeil de Dayan Józefa Hena pod pseudonimem Korab czy nadawanie Archipelagu Gułag przez RWE w 1974 roku. Korespondencja z Giedroyciem to wreszcie zbiór komentarzy bieżących wydarzeń krajowych, dotyczących roku 1989 i okresu transformacji. Odojewski wyłania się z tych listów jako jeden z najlepiej zorientowanych w temacie polityki partner do dyskusji o stanie kraju. Politykę krajową lat 9o. Giedroyć jednoznacznie ocenia jako katastrofalną (1990), jako czas historycznej zapaści (1996). Sugerował Odojewskiemu, by RWE poruszało tematy istotne dla polskiej polityki zagranicznej, przede wszystkim ważne zarówno dla relacji z krajami Europy Zachodniej, jak i dla kwestii polsko-amerykańskich. Jedną z jego propozycji był pomysł sprowadzenia do kraju zwłok ministra Józefa Becka. Pretekstem do nagłośnienia tej sprawy miała być wydana przez Instytut Literacki książka Polska polityka zagraniczna w latach 1926-1939. Na podstawie tekstów min. Józefa Becka autorstwa profesor Anny Cienciały. Giedroyć proponowal, by zaangażować $\mathrm{w}$ to przedsięwzięcie syna ministra, Andrzeja Becka, znaczącą wówczas figurę w amerykańskiej bankowości. Wątek wspomnieniowy miał być okazją do przeglądu polskiej polityki zagranicznej, zwłaszcza że wiele proponowanych rozwiązań ministra pozostawało aktualnych (1990).

Korespondencja z Giedroyciem objaśnia literackie wybory Odojewskiego, przede wszystkim tematy podejmowane przez autora Zasypie wszystko, zawieje... na antenie Radia Wolna Europa, i uświadamia, jak silna relacja łączyła pisarza z redaktorem „Kultury”. Giedroyć chętnie podsuwał Odojewskiemu wątki, na których popularyzowaniu szczególnie mu zależało. Przykładem może być książka Szkice piórkiem Andrzeja Bobkowskiego, podejmująca sprawę okupacji niemieckiej we Francji, drukowana zresztą przez Instytut Literacki w Paryżu (1957), której wartość Giedroyć stanowczo podkreślał i którą uważał za niedocenioną. Sugerował też wydanie jej fragmentów w języku niemieckim (1979). Naturalną konsekwencją tego epistolarnego dialogu wydaje się audycja nadana przez Odojewskiego na antenie RWE w czerwcu 1980 roku 
zatytułowana Druga młodość twórczości A. Bobkowskiego. Wydanie paryskie Szkiców piórkiem oraz inne książki Bobkowskiego Odojewski miał w swojej domowej bibliotece, której część przekazał do Poznania. To oczywiście tylko jeden z wielu przykładów pokazujących rolę Giedroycia w życiu Odojewskiego.

Szczególnie ważnym i wartym szerszego przedstawienia, udokumentowanym w zbiorach poznańskiego archiwum, dowodem tej współpracy jest zainteresowanie Odojewskiego postacią i pisarstwem Józefa Mackiewicza, mającym fundamentalne znaczenie dla tematu Katynia w prozie Odojewskiego. Kontakty z paryską „Kulturą, z którą związany był przecież także autor Buntu rojstów, można uznać za punkt zwrotny w relacji Mackiewicz - Odojewski. Zbiory rzucają nowe światło na zawiłą historię znajomości dwóch znakomitych autorów. Nazwisko Mackiewicza wymieniane jest w listach od maja 1973 roku. Giedroyć informuje Odojewskiego o przysłanym przez Mackiewicza liście do redakcji „Kultury”, w którym wskazuje nieścisłości w jednym z rozdziałów Zasypie wszystko, zawieje... Mowa o tekście Literatura contra faktologia, w którym autor zarzuca Odojewskiemu „zniekształcenie” faktów historycznych zamiast ich „uzupełnienia”, co jest według Mackiewicza rolą powieści. W tym samym liście Giedroyć zaoferował Odojewskiemu pomoc w zorganizowaniu spotkania z Mackiewiczem, by przedyskutowali przedstawione przez niego zastrzeżenia. Pośrednikiem w skontaktowaniu zainteresowanych miał być Michał Tyszkiewicz, którego bratankiem był Jan Tyszkiewicz, związany z RWE (od 1961 roku prowadził dział muzyczny, m.in. audycje „Klub przebojów” i „Godzina bez kwadransa”). Odojewski po raz pierwszy spotkał się z Mackiewiczem dopiero w 1976 roku, ale znali się wcześniej, a ich kontakty ograniczały się do rozmów telefonicznych i listów. Być może tyle zdążył zorganizować Tyszkiewicz, który zmarł w maju 1974 roku. Po spotkaniu pisarzy w 1976 roku po raz pierwszy nadano w RWE program o twórczości Mackiewicza (Zbrodnia w lesie katyńskim). Było to możliwe dopiero po odejściu z rozgłośni niechętnego Mackiewiczowi Nowaka-Jeziorańskiego, którego zastąpił Zygmunt Michałowski. Okoliczności tych wydarzeń Odojewski szczególowo skreślił w wydanym we fragmentach cyklu tekstów poświęconych Mackiewiczowi i Bar- 
barze Toporskiej. Jak się potem okaże, znajomość z Mackiewiczem zaważyła na dalszej twórczości Odojewskiego. Świadczą o tym nie tylko wydane teksty autora Oksany, lecz także pozostawione w maszynopisach audycje Odojewskiego, publikowane na antenie RWE przez cały okres jego pracy dla rozgłośni, które można potraktować jako kronikę tej znajomości. Koniec lat 7o. i początek 80. to w życiu Odojewskiego okres szczególnie intensywnej przyjaźni z Mackiewiczem. W grudniu 1980 i styczniu 1981 roku RWE nadaje dwie audycje o twórczości Mackiewicza przygotowane przez Odojewskiego (jako Wacław Kondratowicz), zatytułowane Józef Mackiewicz-Byłem w Katyniu - Dziennik żotnierza oraz Józef Mackiewicz i jego twórczość. Dotyczyły one przede wszystkim katyńskiej relacji autora Drogi donikąd. Można więc założyć, że okres powstawania opowiadania Ku Dunzynańskiemu Wzgórzu idzie las pokrywa się z intensywnym namysłem Odojewskiego nad twórczością Mackiewicza. W Raptularzu krytycznym pisarz wspominal:

Nasze stosunki szczególnie się zacieśniły w okresie stanu wojennego i potem. O tych telefonicznych rozmowach rozciągniętych na wiele, wiele minut (a później jeszcze oddawał słuchawkę żonie, Barbarze i znowu była długa rozmowa), to mógłbym mówić w nieskończoność. [Odojewski 1994: 60]

W innym fragmencie stwierdza: „Duża część tych rozmów dotyczyła obu nas nieustannie obchodzącej sprawy Katynia - co można dla tej sprawy zrobić, gdzie i jak ją nagłośnić” [Odojewski 1994: 58].

Wątek katyński pojawiający się na antenie RWE w 1980 i 1981 roku związany jest z czterdziestą rocznicą zbrodni. Rok 1980 stanowi ważny kontekst dla powstania opowiadań z tomu Zabezpieczanie śladów, wydanego w 1984 roku przez Instytut Literacki w Paryżu, przedstawiających tragiczne losy Polaków przymusowo wywożonych na Wschód. Podobna tematyka pojawia się $\mathrm{w}$ audycjach przygotowanych przez Odojewskiego w tym czasie. Oprócz wspomnianych wcześniej, poświęconych Mackiewiczowi, wskazać warto 4o-lecie zbrodni katyńskiej (emisja 27 kwietnia 1980 
roku) oraz Antypolski album wyd. w Sowietach (emisja 6 września 1980 roku). Ujawnienie prawdy o Katyniu było jednym $\mathrm{z}$ haseł sierpnia 1981. Potem w RWE nadano audycję wspomnieniową po śmierci Mackiewicza w 1984 roku i kilka programów w latach 90. (np. w cyklu „Czasy zwykłe, czasy ciekawe” nadano 26 sierpnia 1990 roku audycję Sprawa Mackiewicza; jest to obrona pisarza przed oskarżeniami o kolaborację i refleksje autora audycji z tym związane). Temat zbrodni katyńskiej powraca w twórczości Odojewskiego wraz z powieścią Katyń. Milczacy, niepokonani.

Jeden z ostatnich listów Giedroycia dotyczący sprawy Mackiewicza, napisany w listopadzie 1990 roku, zawiera wymowną deklarację, że „Kultura” nigdy nie brała udziału w nagonce na autora Kontry z powodu jego „kolaboracji”, ale zdecydowanie go broniła, co było powodem konfliktu z Nowakiem-Jeziorańskim. Kolejne tropy prowadzą do korespondencji z Andrzejem Wajdą, którą Odojewski prowadził w latach 2001-2003. Pozostajemy zatem w obszarze tej samej tematyki. Obok zapisanej w listach historii realizacji projektu filmu o zbrodni w Katyniu i okoliczności zerwania współpracy (komentowane w mediach) utrwalona została wymiana myśli dwóch genialnych twórców na rozmaite ważkie tematy.

W czasie krystalizowania się koncepcji filmu o Katyniu Wajda intensywnie pracował nad filmową adaptacją Zemsty Aleksandra Fredry. Na bieżąco informował Odojewskiego o zbliżającej się finalizacji komedii, co oznaczało, że wkrótce będzie można zająć się Niepokonanymi, bo taki był roboczy tytuł projektu. Mając świadomość tego, jak potrzebny jest ten film, Wajda obawiał się, że ktoś inny zajmie się tym tematem wcześniej. Nalegał więc, by ogłosić w mediach informację o rozpoczęciu prac. Jego obawy nie były bezpodstawne. W tym samym czasie dwa filmy o Katyniu zamierzał przygotować Robert Gliński. Miały one nosić tytuły Sanatorium Gorkiego oraz Las. Pomysły Glińskiego upadly jednak $\mathrm{w}$ fazie przedprodukcyjnej.

Wajda żywo reagował na to, co dzieje się wokół filmu, a swoje wrażenia przedstawiał Odojewskiemu w listach. Relacjonował pisarzowi m.in. swoją rozmowę z rosyjskim Ministrem Kultury przebywającym w Warszawie przy okazji wizyty Władimira Putina, 
który z aprobatą przyjął informację o udziale Rosjan w filmie. Była to dla reżysera kwestia niezwykle ważna. Zdawał sobie sprawę, jakim wyzwaniem jest stworzenie pierwszego filmu o zbrodni katyńskiej. Wiedzial, że wśród publiczności wielu będzie oczekiwało przedstawienia całej dostępnej wiedzy o tej sprawie i odpowiedzi na pytanie, dlaczego to mogło się wydarzyć. Stąd trafionym i jedynie słusznym pomysłem wydawało się ograniczenie opowieści i przedstawienie jej z perspektywy rodziny prokuratora Romana Martiniego, którego pisarz uczynił centralnym bohaterem opowieści. To właśnie jego osoba stała się przedmiotem dyskusji Odojewskiego i Wajdy.

Martini w czasie II wojny światowej brał udział w kampanii wrześniowej. Po kapitulacji został osadzony w obozie jenieckim w Woldenburg (obecnie Dobiegniew), gdzie więziony był do stycznia 1945 roku. Po wojnie zgłosił się do służby w wymiarze sprawiedliwości. Przydzielono mu stanowisko wiceprokuratora w krakowskim sądzie specjalnym, gdzie zajmował się zbrodniami wojennymi popełnionymi przez Niemców. Jego zadaniem było przeciwdziałanie rozpowszechnianiu wśród polskiego społeczeństwa informacji o zbrodni sowieckiej dokonanej w Katyniu. W marcu 1946 roku został brutalnie zamordowany. Śledztwo wykazało, że była to zemsta za uwiedzenie szesnastoletniej Jolanty Słapianki. Do morderstwa przyznał się zakochany w niej Stanisław Wróblewski, po procesie skazany na karę śmierci i stracony. Jest też nieoficjalna wersja zdarzenia, według której Martini zginął, bo podczas podróży do Związku Radzieckiego odnalazł materiały obciążające Rosjan [Dramat prokuratora Martiniego 2010]. W Milczacych, niepokonanych Odojewski przypomnial podjętą na przełomie lat 1945 i 1946 próbę zainscenizowania procesu w sprawie zbrodni katyńskiej, mającego udowodnić winę Niemców. Martini został tu przedstawiony jako młody prokurator badający sprawę zbrodni katyńskiej. Ma on osobisty stosunek do śledztwa, bowiem w Katyniu zginął jego brat Andrzej, dlatego żąda ukarania winnych. W powieści Martini jest naiwną ofiarą manipulacji i bezwzględności sowieckiej. Wątpliwości Wajdy budziła kwestia podróży prokuratora do Charkowa i fakt, że w tamtych czasach nie było dowodów na winę Sowietów. Zbyt wiele wątków nieoficjalnej wer- 
sji życia i okoliczności śmierci prokuratora miało według reżysera przeniknąć do powieści Odojewskiego. Wersja powieściowa nie oddawała rzeczywistości.

Ostatecznie to świetnie zapowiadające się przedsięwzięcie nie doszło do skutku, a współpraca pisarza i reżysera zakończyła się 24 września 2003 roku. Wajda oznajmił Odojewskiemu w liście, że zarzuca projekt realizacji filmu w formie przez niego zapisanej. Uznał, że nie będzie w stanie przełożyć go na filmowy scenariusz. Jednym z powodów tej decyzji była konstrukcja postaci prokuratora Martiniego, wybranego przez pisarza na bohatera filmu. To wersja oficjalna. Druk Milczacych, niepokonanych był sprawą osobną, niezależną od procesu realizacji filmu. Powieść ukazała się w 2003 roku.

\section{Dossier biograficzno-edytorskie}

Licząca setki listów korespondencja Odojewskiego pozwala osadzić proces twórczy w szerokim kontekście biograficznym. Listy od Giedroycia przybliżają historię pierwszego wydania arcydzieła Odojewskiego, Zasypie wszystko, zawieje... Daty listów, w których znajdziemy informację o przygotowaniach powieści do druku, pozwalają ustalić kolejne etapy procesu wydawniczego, a jest to działanie szczególnie istotne dla genetycznych badań nad twórczością Odojewskiego. Z korespondencji dowiadujemy się, że w korektę fragmentów w języku ukraińskim byli zaangażowani Bogdan Osadczuk, Iwan Koszeliwiec i Borys Lewicki. Paryskie wydanie powieści przypadło na początki pracy Odojewskiego w RWE i, jak wynika z listów, był to dla pisarza czas szczególnie trudny, kiedy musiał sobie poradzić z nowymi obowiązkami i zorganizować prace redakcyjne nad książką. Inny rozdział historii powieści Zasypie wszystko, zawieje... stanowi korespondencja z Noem Wertsheiserem (1915-1985), który do czasu emigracji z Polski w 1967 roku współpracował z Teatrem Polskiego Radia jako autor słuchowisk ogłaszanych pod pseudonimem Michał Tonecki. Był też twórcą sztuk teatralnych i scenariuszy filmowych. Odojewski [2010: 82-87] po latach opublikował poświęcone Wertsheiserowi opowiadanie, dając wyraz zażyłości, jaka istniała 
między nimi w czasach wspólnej pracy na Myśliwieckiej [zob. też Tumiłowicz 2008]. Z prowadzonej intensywnie w latach 1971-1995 korespondencji obu pisarzy wyłania się dyskusja o językowym kształcie Zasypie wszystko, zawieje...: Odojewski konsultował z Wertsheiserem m.in. detale dotyczące dialektów używanych na Podolu. Listy pomagają przyporządkować poszczególne wersje brulionowe do okresów twórczości Odojewskiego, choć są to oczywiście wskazania przybliżone.

\section{Przed-tekst. Geneza cyklu podolskiego}

Odojewski pozostawił setki maszynopisów, w znacznej części niedatowanych. Większość napisanych przez niego utworów (od kilku do kilkudziesięciu) to wersje zachowane w formie maszynopisów, powstające $\mathrm{w}$ różnych fazach jego twórczości, często uzupełniane fragmentami rękopiśmiennymi. Bezustannie udoskonalał swoje dzieła: zapisywał całe marginesy, doklejał dodawane passusy do tekstu głównego, notował między wierszami i na odwrocie kart. Korzystał nie tylko z maszynopisów, ale także z kserokopii tekstów wydanych. Poprawki nanosił również w opublikowanych książkach. Stanowią one zupełnie odrębne warianty utworów. Taka metoda twórcza sprawia, że właściwie żadnego z tekstów autora Oksany nie możemy uznać za wersję ostateczną danego utworu. Wszystkie składają się na zasób określony przez krytyków genetycznych jako „przed-tekst”7. Śledzenie zmian w tekstach niewydanych, porównywanie z wszystkimi edycjami umożliwia odtworzenie i analizę poszczególnych etapów procesu twórczego i pisarskiej aktywności autora.

Analiza pozostawionych przez Odojewskiego dokumentów twórczej pracy skłania do zabiegów zmierzających do ustalenia

7 Pierre-Marc de Biasi [2015: 53] definiuje przed-tekst jako wygenerowany z pisarskiej spuścizny zestaw dokumentów, które pozwalają prześledzić genezę tekstu: „Przed-tekst jest rezultatem pracy badacza: powstał w wyniku przekształcenia istniejącego realnie zbioru nieprzejrzystych dokumentów w zespół elementów uporządkowanych i znaczących [...]: plany, szkice, brudnopisy, czystopisy, dokumentacja, rękopis ostateczny itd., odcyfrowane, ewentualnie przepisane, a zwłaszcza w całości posegregowane w kolejności powstawania i w zgodzie z logiką ich wzajemnych zależności”. 
okoliczności powstawania cyklu podolskiego, do tej pory niejasnych ze względu na trudną do rekonstrukcji historię początków utworów, które go tworzą. Przypomnijmy pokrótce, że opus magnum Odojewskiego, w świetle historii edycji jego tekstów, bierze swój początek w roku 1962, z chwilą opublikowania Zmierzchu świata, a jego zwieńczeniem jest wydana dekadę później monumentalna powieść Zasypie wszystko, zawieje... Usytuowana pomiędzy nimi Wyspa ocalenia z 1964 roku jest wersją utworu o tym samym tytule, który powstał już w 1950 roku, był zatem właściwym debiutem prozatorskim Odojewskiego. Powieść otrzymała wówczas Nagrodę im. Tadeusza Borowskiego, a jej fragment wyemitowało Polskie Radio. Ta pierwotna wersja Wyspy ocalenia nie zachowała się $\mathrm{w}$ archiwum pisarza ani też $\mathrm{w}$ archiwum radiowym. Brak tekstu pozwala zatem na jedynie hipotetyczne wskazanie momentu, w którym cykl podolski zaczął powstawać. W późnych latach 5o. i na początku 6o. ubiegłego stulecia Odojewski przygotowuje teksty, których fabuła dotyczy historii rodzinnej Woynowiczów i Czerestwienskich: niektóre utwory z niewydanych, a przygotowanych do edycji w 1957 roku, tomów Codzienna ściana płaczu oraz Bez dogmatów ${ }^{8}$, z opublikowanej trzy lata później Kwarantanny (Luminal) [Odojewski 1960], fragment powieści Małe zepsute mechanizmy [Odojewski 1961] ogłoszony we „Współczesności”, zatytułowany Po tamtej stronie oceanu [Odojewski 1957] (notabene gruntownie przepracowana wersja opowiadania, które Odojewski zamieścił wcześniej w „Tygodniku Zachodnim"). Dodajmy do tej bibliografii jeszcze fakt kontynuacji przez Odojewskiego cyklu podolskiego w postaci niewydanej w całości, powstającej na przestrzeni wielu lat Powieści berlińskiej, która w kilku opasłych teczkach zachowała się w archiwum pisarza. Geneza cyklu podolskiego w świetle pozostawionej dokumentacji wydaje się pilnym zadaniem dla badaczy twórczej biografii autora Oksany. Wymaga jednak spojrzenia na najważniejsze jego dzieło z perspektywy procesu twórczego, a nie porządku publikacji. rych edycję wstrzymała interwencja cenzury, znajdują się obecnie w Archiwum Wydawnictwa Poznańskiego w zbiorach Biblioteki Raczyńskich w Poznaniu. 
Zaprezentowany zestaw zagadnień, wynikających z porządkowania i analizy pozostawionej przez Odojewskiego dokumentacji, podlega nieustannej weryfikacji w toku pracy. Archiwum, pozwalając badaczowi wpatrywać się w bezmiar zapisanych drobnym pismem kartek i wsłuchiwać się w wielogłos własnej materii, nieustannie stawia pytania.

\section{Bibliografia}

Antoniuk Mateusz, red. (2017) Pracownia Herberta. Studia nad procesem tekstotwórczym, Wydawnictwo Uniwersytetu Jagiellońskiego, Kraków.

Balcerzan Edward (1975), Biografia jako język, w: Biografia - geografia kultura literacka, red. Janusz Sławiński i Jerzy Ziomek, Ossolineum, Wrocław, s. 25-40.

Biasi Pierre-Marc de (2015), Genetyka tekstów, przeł. Filip Kwiatek, Maria Prussak, IBL PAN, Warszawa.

Dabertowa Eugenia R. (2005), Taśma życia Przemystawa Bystrzyckiego, Bonami, Poznań.

Dramat prokuratora Martiniego (2010), [online], [dostęp: 15 października 2018], https://www.nck.pl/projekty-kulturalne/projekty/ pamietam-katyn-1940/aktualnosci/dramat-prokuratora-martiniego.

Iwasiów Inga (1994), Kresy w twórczości Wtodzimierza Odojewskiego. Próba feministyczna, Jota, Szczecin.

Mackiewicz Józef (1973), Literatura contra faktologia, „Kultura”, nr 7-8, s. $182-183$.

Nowakowska Dagmara (2014), Wielkopolska Włodzimierza Odojewskiego. Przyczynek do biografii, „Przegląd Wielkopolski”, nr 3, s. 5-13.

Nowakowska Dagmara (2016), Poznańskie Archiwum/Pracownia Wtodzimierza Odojewskiego, „Fraza”, nr 4, s. 54-61.

Nowakowska Dagmara, Nawrot Jolanta, Krystek Jędrzej (2019), Archiwum pisarskie Włodzimierza Odojewskiego w świetle krytyki genetycznej [referat wygłoszony na konferencji Przed-tekstowy świat II: polska krytyka genetyczna - badania i perspektywy, Łódź, 22-23 maja 2017 roku], „Acta Universitatis Lodziensis. Folia Litteraria Polonica”, nr 4 [tekst w druku].

Odojewski Włodzimierz (1957), Po tamtej stronie oceanu, „Tygodnik Zachodni”, nr 33, s. 5. 
Odojewski Włodzimierz (1960), Kwarantanna, Czytelnik, Warszawa.

Odojewski Włodzimierz (1961), Małe zepsute mechanizmy,

„Współczesność”, nr 2, s. 3-4.

Odojewski Włodzimierz (1994), Józef Mackiewicz po latach, w: tegoż, Raptularz krytyczny, Wydawnictwo umCs, Lublin, s. 57-62.

Odojewski Włodzimierz (200o), Spisywane z pamięci, w: tegoż, Jedźmy, wracajmy i inne opowiadania, Wydawnictwo Książkowe Twój Styl, Warszawa, s. 327-350.

Odojewski Włodzimierz (2010), Noe, „Fraza”, nr 1, s. 82-87.

Przybyszewska Alicja (2018), Poznańskie lata Wtodzimierza Odojewskiego.

Przyczynek do kalendarium życia i twórczości (i edycji książek

zaniechanych), w: Zabezpieczanie śladów. Wokót życia i twórczości

Wtodzimierza Odojewskiego, red. Alicja Przybyszewska, Dagmara

Nowakowska, Wydawnictwo „Poznańskie Studia Polonistyczne”,

Poznań, s. 93-104.

Rabizo-Birek Magdalena (2002), Między mitem a historią. Twórczość

Włodzimierza Odojewskiego, Wydawnictwo Książkowe Twój Styl,

Warszawa.

Sztaba Joanna, Sarkady Antoni, red. (2010), Saga rodu Bystrzyckich.

Przedsiębiorcy, urzędnicy, literaci, uczeni, zesłańcy..., Muzeum

Narodowe Ziemi Przemyskiej, Przemyśl.

Tumiłowicz Bronisław (2008), Literacki alfabet Włodzimierza

Odojewskiego [online], [dostęp: 11 października 2018], https://www.

tygodnikprzeglad.pl/literacki-alfabet-wlodzimierza-odojewskiego/.

Wirpsza Witold (1980), List Witolda Wirpszy do Wtodzimierza

Odojewskiego z 11 maja 1980 r., Archiwum W. Odojewskiego

w Poznaniu.

Dagmara Nowakowska, Alicja Przybyszewska

A writer in the archive. The work on the Archive of Włodzimierz

Odojewski in Poznań

The article is a collection of thoughts that transpired during the work at the Archive of Włodzimierz Odojewski. The aim of the authors was to identify and indicate the potential ways to study the life and works of the writer, and the expected result of the research is a biography of Odojewski. The research was based on the exploration of the writer's private collection: unpublished documents, manuscripts, typescripts, personal papers, correspondence, family and estate papers and photographs. The authors focused on a number of issues. One, the biographical facts that influenced Odojewski's output - World War II, frequent relocations, censorship and 
a ban on publishing in Poland, emigration, the relation with the Polish Institute in Maisons-Laffitte and working at Radio Free Europe's editorial office. Two, the analysis of literary works including hundreds of typescripts in many variants (related to the phases of the genetic history of a literary work through the stages of Odojewski's life) which allowed for describing Odojewski's writing techniques. Three, 'The writer's map' which points out places important for the author - Poznań, Gniezno, Kłecko, Podole, Szczecin, Warsaw, Paris, Berlin, Munich. Four, the correspondence (personal and cultural) which can be used as an important source of knowledge of the history of Polish post-war emigration. One of the most interesting parts of the collection is a collection of letters from Jerzy Giedroyć that show Polish culture outside the Iron Curtain.

Keywords: Włodzimierz Odojewski; archive; biography; genetic criticism; Polish post-war emigration.

Alicja Przybyszewska - doktor nauk humanistycznych w dziedzinie literaturoznawstwa; absolwentka Wydziału Filologii Polskiej i Klasycznej UAM. Jej zainteresowania badawcze skupiają się wokół archiwów pisarskich twórców związanych z Poznaniem i Wielkopolską, dokumentacji aktywności środowiska literackiego regionu, a także historii teatru poznańskiego przełomu XIX i XX wieku. Autorka monografii „Etyczny utylitarysta”. Edmund Rygier $w$ Teatrze Polskim w Poznaniu 1896-19o8 (2016) oraz opracowań: Katalog rękopisów Ośrodka Dokumentacji Wielkopolskiego Środowiska Literackiego, t. 5: Spuścizna literacka Mariana Grześczaka (2018), Repertuar Teatru Polskiego w Poznaniu za dyrekcji Franciszka Dobrowolskiego 1883-1996 (2015) i „Arkusz”. Bibliografia zawartości 1991-2003 (2012). Opracowała szereg wystaw biograficzno-literackich. Publikowała m.in. w „Kronice Miasta Poznania”, „Pamiętniku Teatralnym”, „Poznańskich Studiach Polonistycznych. Serii Literackiej”.

Dagmara Nowakowska - dokumentalista, autorka rozprawy doktorskiej Indie romantyków. $Z$ recepcji Indii w epoce polskiego romantyzmu. Interesuje się życiem polskiej powojennej emigracji intelektualnej, historią europejskiej indologii, biografistyką i regionalistyką literacką. Współpracuje z Wielkopolskim Towarzystwem Kulturalnym. Publikowała w czasopismach naukowych (m.in. „Studia Norwidiana”, „Pamiętnik Literacki”) i w tomach zbiorowych. Jest współredaktorką książki Zabezpieczanie śladów. Wokót twórczości Wtodzimierza Odojewskiego. 